\title{
THE USE OF HUMAN TEETH IN IDENTIFICATION: EPIDEMIOLOGICAL DATA FROM AN ANTHROPOLOGY LAB IN BRAZIL
}

\author{
O USO DE DENTES HUMANOS NA IDENTIFICAÇÃO: DADOS \\ EPIDEMIOLÓGICOS DE UM LABORATÓRIO DE ANTROPOLOGIA NO BRASIL
}

\section{Raffaela Arrabaça FRANCISCO ${ }^{1}$; Maria Isabel de Oliveira e Britto VILLALOBOS ${ }^{2}$; Adrielly Garcia ORTIZ ${ }^{3}$; Maria Gabriela Haye BIAZEVIC ${ }^{4}$; Marco Aurelio GUIMARÃES ${ }^{5}$; Ricardo Henrique Alves Da SILVA ${ }^{6}$}

1. Pós Doutoranda, Faculdade de Medicina de Ribeirão Preto - USP, Ribeirão Preto, SP, Brasil. raffaela@ usp.br; 2. Mestranda em Clínicas Odontológicas - PUC Minas e Especialista em Odontologia Legal - FORP/USP, Ribeirão Preto, SP, Brasil; 3. Especialista em Odontologia Legal, Faculdade de Odontologia de Ribeirão Preto - USP, Ribeirão Preto, SP, Brasil; 4. Professora, Pós Doutora, Faculdade de Odontologia de São Paulo - USP, Ribeirão Preto, SP, Brasil; 5. Professor Doutor, Faculdade de Medicina de Ribeirão Preto - USP , Ribeirão Preto, SP, Brasil; 6. Professor, Doutor, Faculdade de Odontologia de Ribeirão Preto - USP , Ribeirão Preto, SP, Brasil.

\begin{abstract}
Forensic Odontology is a branch of Dentistry that works with the Law in assisting Justice and the professional involved in this specialty helping the identification of human remains, in various situations - charred corpses, cadavers and unidentified bodies. The aim of this paper was to list and analyze the number and types of teeth present in cadavers submitted to the Forensic Anthropology Lab of the Forensic Medicine Center (Ribeirão Preto), from 2005 to 2010, in order to evaluate and compare the importance of each dental element in human identification. During the research, the Lab received, inserted or submitted with the cadavers, for anthropological analysis, 588 teeth, of which 303 were upper teeth and 285 lower teeth. The upper teeth mostly found were the first and second molars ( $\mathrm{n}=48)$ and the mostly found lower teeth were canines and first bicuspids $(\mathrm{n}=44)$. The most absent upper tooth ante mortem was the third molar $(n=25)$ and, on the lower arch, the first molar $(n=33)$. In contrast, the most absent teeth post mortem on the upper dental arch were central and lateral incisors $(n=23$ and $n=20$, respectively) and on the lower arch the same dental elements (central incisors - $n=37$, lateral incisors $-n=28$ ). The techniques for estimating age, ancestry, stature and gender by analysis of dental characteristics varied according to the population. In Brazil, due to the wide population miscegenation, the techniques mentioned may not present the same level of reliability, making it necessary to associate the dental exam to the anthropological analysis, in order to reach the most scientifically reliable results. It was concluded that, due to the importance of the dental elements in the process of human identification, it is necessary the presence of a dental surgeon in the team to collect the remains and perform the identification.
\end{abstract}

KEYWORDS: Forensic Dentistry. Forensic Medicine. Forensic Anthropology. Tooth.

\section{INTRODUCTION}

Forensic Odontology is an area of Dentistry that works with the Law to assists the Justice. The dentist who works in forensics aids for human identification, in cases where the remains are unable for legal recognition, as in the case of charred bodies, bones and bodies in an advanced decomposition stage, should work at Institutes of Forensic Medicine, provided expert criminal linked to Police services or even for judicial appointment to play the role of expert (HILL; HEWSON; LAIN, 2011).

The primary methods for human identification are fingerprint analyses, dental examination and DNA (PRETTY; SWEET, 2001; INTERPOL, 2015). Between all tissues of the human body, the teeth have the best resistance to post-mortem changes and, for this reason, it can be used to estimate people's age, sex, ancestry and height. The result of the dental analysis is not always conclusive, depending on the quality of antemortem records. However, coupled with other information, such as anthropological examination, dental elements can perform a positive identification (LOVEJOY et al, 1985).

The objectives of this study were to describe the dental elements present in a service of Physical Anthropology, in Brazil, between 2005 and 2010, as well as to investigate the potential contribution of each tooth in dental identification.

\section{MATERIAL AND METHODS}

The research was conducted in Ribeirão Preto, São Paulo State, Brazil. Between January 2005 and December 2010, 65 human remains, viable for analysis, were received at the Forensic Anthropology Lab (LAF) of the Forensic Medicine Center (CEMEL).

The presence or absence of various dental elements was recorded, according to the following 
criteria: it was considered present when the tooth was in the dental arch, which may be intact, or only the remaining root; absent ante-mortem those with the blister healed bone formation; absent postmortem those who possessed the empty socket and unhealed; and no information in the case of bones conveyed without the mandible or jaw.

The information from teeth analyzed in this work were organized and tabulated in order to allow quantitative analysis of the data using simple descriptive statistics. It was also used the nonparametric test $\chi^{2}(\alpha \leq 0.05)$ for the variable presence or absence of teeth - ante-mortem, perimortem or post-mortem (ZAR, 1999).

\section{RESULTS}

For the analysis of teeth more and less submitted to LAF/CEMEL, it was verified the number of cases when the tooth was present or absent, and among the absent are the absent antemortem, absent post-mortem and absent without information (usually due to lack of mandible or maxilla, or because they have not been found at the site of collection).

During the research established between days January $1^{\text {st }} 2005$ and $31^{\text {st }}$ December 2010, the LAF/CEMEL received 65 corpses for anthropological analysis, and inserted or referred to these bones together, a total of 588 dental elements, of which 303 were upper teeth and 285 were lower. The first and second molars were the most found upper teeth $(n=48)$, whereas the canines and the first pre molar were the most frequent lower ones $(\mathrm{n}=44)$. The upper tooth missing more ante-mortem was third molar $(\mathrm{n}=25)$ and in the lower arch the first molar $(\mathrm{n}=33)$. In turn, more missing teeth post-mortem, the upper dental arch were the central incisor $(\mathrm{n}=23)$ and in the lower arch, the same dental element (central incisors, $\mathrm{n}=37$ ). In addition, the teeth with the smallest number of information in both arches (upper and lower) were the third molar $(\mathrm{n}=22$ and $\mathrm{n}=23$, respectively), as shown in Table 1.

Table 1. Dental elements, Forensic Anthropology Lab, Ribeirão Preto, Brazil, 2005-2010.

\begin{tabular}{|c|c|c|c|}
\hline Tooth & Rating & Upper Dental Arch & $\begin{array}{c}\text { Lower } \\
\text { Dental } \\
\text { Arch }\end{array}$ \\
\hline \multirow{4}{*}{$\begin{array}{l}\text { Central } \\
\text { Incisor }\end{array}$} & Present & 25 & 20 \\
\hline & Absent Ante-Mortem & 20 & 09 \\
\hline & Absent Post-Mortem & $23 * * *$ & $37 * * *$ \\
\hline & No Information & 16 & 18 \\
\hline \multirow{4}{*}{$\begin{array}{l}\text { Lateral } \\
\text { Incisor }\end{array}$} & Present & 33 & 32 \\
\hline & Absent Ante-Mortem & 16 & 09 \\
\hline & Absent Post-Mortem & 20 & 28 \\
\hline & No Information & 15 & 16 \\
\hline \multirow{4}{*}{ Canine } & Present & 40 & $44 *$ \\
\hline & Absent Ante-Mortem & 16 & 09 \\
\hline & Absent Post-Mortem & 15 & 15 \\
\hline & Sem Informação & 13 & 16 \\
\hline \multirow{4}{*}{ 1st premolar } & Present & 45 & $44^{*}$ \\
\hline & Absent Ante-Mortem & 19 & 11 \\
\hline & Absent Post-Mortem & 09 & 12 \\
\hline & No Information & 11 & 17 \\
\hline \multirow{4}{*}{ 2nd premolar } & Present & 36 & 38 \\
\hline & Absent Ante-Mortem & 19 & 17 \\
\hline & Absent Post-Mortem & 17 & 12 \\
\hline & No Information & 12 & 17 \\
\hline \multirow{3}{*}{ 1st molar } & Present & $48^{*}$ & 30 \\
\hline & Absent Ante-Mortem & 19 & $33 * *$ \\
\hline & Absent Post-Mortem & 03 & 04 \\
\hline
\end{tabular}




\begin{tabular}{|c|c|c|c|}
\hline & No Information & 14 & 17 \\
\hline \multirow{4}{*}{ 2nd molar } & Present & $48 *$ & 42 \\
\hline & Absent Ante-Mortem & 19 & 23 \\
\hline & Absent Post-Mortem & 03 & 05 \\
\hline & No Information & 14 & 14 \\
\hline \multirow{4}{*}{ 3rd molar } & Present & 28 & 35 \\
\hline & Absent Ante-Mortem & $25 * *$ & 22 \\
\hline & Absent Post-Mortem & 09 & 04 \\
\hline & No Information & $22 * * * *$ & $23 * * * *$ \\
\hline
\end{tabular}

*Sent more teeth; **Teeth less submitted ante-mortem; ***Teeth less submitted post-mortem; ****Teeth without information

\section{DISCUSSION}

A review of sex through the cusps of the molars was also described by another author by measuring the cusps and the application of a mathematical formula that achieved an accuracy of $75-80 \%$ of the sex of the individuals; however, this technique does not relieve the assessment of sex through the pelvis, considered the most suitable (MACALUSO, 2011). Through the measures buccal-lingual and mesial-distal molars, some authors concluded that the mesial-distal measures are best for determining the sex of the buccallingual (ACHARYA; MAINALI, 2008). But, as the first permanent tooth to erupt, the first molar is a tooth that often presents restorations, carious lesions and may even be absent (MACALUSO, 2011). In the sample this tooth was the fewer teeth found in the dental arches bones.

In the study of a skeletons collection from Greece, the teeth that showed greater sexual dimorphism were the lower second and third molars (ZORBA et al, 2012).

A study that examined the incidence of anterior teeth lost in the Brazilian population noted that, between the upper teeth, central and lateral incisors were the most absent. While in the lower teeth, a pattern was not observed. The same study found that caucasians had lower proportion of missing teeth than other ethnic groups, and women were more likely to miss their teeth than men (LOPEZ; BIAZEVIC; MICHEL-CROSATO, 2010). Our study found similar results.

The upper canine teeth are among the most commonly found in the samples, and it could be used to estimate age, being greater functionality with teeth in the mouth, generally do not have cavities and are single-rooted, area large with pulp, the factors have potential to facilitate the analysis (CAMERIERE et al, 2009). This same technique, in which the age is estimated by measuring the pulp chamber can also be used with premolars. This technique is performed by measuring the amount of dentine and enamel and it is known that women have more dentin and enamel that most men (PRETTY; SWEET, 2001).

When it comes to post-mortem traces, the most frequently missing tooth were the incisors, probably due to lack of care at the time of collection of human remains, being single-rooted and small, often fall to the ground, and teeth may be confused with stones and therefore are not collected. This situation could be avoided with the presence of forensic odontologists, the withdrawal of the remnants of the crime scene and in transport to the responsible entity. So, it is a limitation of our study the fact that many dental elements were lost during the handling of human remains to the Laboratory analysis (LAF/CEMEL).

According to the technique developed by Gustafson, the entire dentition can be used for analysis of surface wear of occlusion, periodontosis, secondary dentine inside the pulp cavity, root cementum deposition, root resorption and transparency of the apex. Evaluating each of these points, we obtain a sum that will generate the average age (GUSTAFSON, 1950).

The third molars help in estimating the age of individuals, through the evaluation of the various stages of mineralization. In Brazil, this is a very valuable information because it assists in the verification of Justice issues related to liability, which is the ability of the agent to understand that the act done is a crime and, according to the understanding, or not be punished for the offense committed, and by means of the method of Demirjan achieved indicate the stage of mineralization of the tooth and thus indicate the age, provided that the individual has up to 21 years since, after that age, the third molar already completely mineralized (JAYAMARAN et al, 2011; MEGYESI; UBELAKER; SAUER, 2006). However, should analyze the methods with caution, 
as they may not be applicable to various populations (JAYAMARAN et al, 2011).

In our sample, such a technique would be of little use, since most of the third molars were absent or without ante-mortem information. Other authors conducted a study in Iran to assess calcification of third molars using the Demirjan modified technique, and concluded that there were no differences in the stages of calcification between men and women (MEINL et al, 2008; JAFARI et al, 2012). Another study found different results in women present mineralization later than men (GUO et al, 2012).

Through the analysis of several dental elements is also possible to estimate ancestry (OLIVEIRA et al, 2012), gender (SONIKA et al, 2011) and age (ANUTHAMA et al, 2011; FEIJÓO et al, 2012). Estimates of ancestry are shown in several studies, in which we analyze the shape of the upper incisor. One of the findings is the format found in shovel incisors Asiatic (HILL; HEWSON; LAIN, 2011; GUSTAFSON, 1950). This, however, is a technique for identification restricted to ancestry issues.

The ancestry can be estimated by observing the presence of the Carabelli cusp, found in upper molars of Caucasians (KIMURA et al, 2009; KRAUS, 1951). The first molar dental element was found in this sample, which would help in the ancestry estimation, however, as in Brazil, site of our study, there is a broad mixture of different ethnic groups, so, the presence of this cusp indicate that the suspect can be caucasian or mixed ancestries. According to the cusps design of the first molars, it is possible to classify the individual as caucasian, mongoloid or negroid, however, healthy teeth must be found (SCHULLER-GOTZBURG; SUSCHANEK, 2007). And, being the first permanent tooth to erupt, the first molar is a tooth that often presents restorations, carious lesions and may even be absent (MACALUSO, 2011). In the sample in question, this was one of fewer teeth found in the dental arches bones.

Besides the aforementioned limitation of the study, the need for greater care in handling with remains from the work team, other studies are needed in other regions from Brazil, where social and economic differences could possibly bring different results with regard with the oral health population condition.

Dentistry contributes actively in the process of human identification. It is a method that has numerous findings that can generate the profile that will lead to the identity of human remains. The techniques have the fact that each dentition is unique in common, which means that the potential for identifying an individual records in the presence of ante-mortem are high. We conclude that the proper collection of human remains at the scene and the presence of the dentist forensic elements are essential to the success of the identification work.

RESUMO: A Odontologia Forense é um ramo da odontologia que trabalha com a Lei na assistência à Justiça e ao profissional envolvido nessa especialidade especialmente ajudando na identificação de restos humanos, em várias situações - corpos carbonizados, cadáveres e corpos não identificados. O objetivo deste trabalho foi o de listar e analisar o número e tipos de dentes presentes em cadáveres submetidos a exame no Laboratório de Antropologia Forense do Centro de Medicina Legal (Ribeirão Preto), de 2005 a 2010, a fim de avaliar e comparar a importância de cada elemento dental para identificação humana. Durante a pesquisa, o laboratório recebeu 588 dentes inseridos ou juntos aos cadáveres para análise antropológica, destes 303 eram dentes superiores e 285 dentes inferiores. Os dentes superiores mais encontrados foram os primeiros e segundos molares $(n=48)$ e os dentes inferiores mais encontrados foram os caninos e pré-molares $(n$ = 44). O dente superior com maior ausência ante-mortem foi o terceiro molar $(\mathrm{n}=25)$ e, na arcada inferior, o primeiro molar ( $n=33$ ). Em contrapartida, o dente mais ausente post-mortem na arcada dentária superior foram os incisivos centrais e laterais $(n=23$ e $n=20$, respectivamente) e na arcada inferior os mesmos elementos dentários (incisivos centrais - $n=37$, incisivos laterais - $n=28$ ). As técnicas para estimar a idade, ascendência, estatura e sexo através da análise das características dentárias variou de acordo com a população. No Brasil, devido à ampla miscigenação da população, as técnicas mencionadas podem não apresentar o mesmo nível de confiabilidade, tornando-se necessário associar o exame odontológico à análise antropológica, a fim de alcançar resultados mais confiáveis cientificamente. Concluiu-se que, devido à importância dos elementos dentários no processo de identificação humana, é necessária a presença de um cirurgião-dentista na equipe para recolher os restos humanos e executar a identificação.

PALAVRAS-CHAVE: Odontologia Legal. Medicina Legal. Antropologia Forense. Dente. 


\section{REFERENCES}

ACHARYA, A. B.; MAINALI, S. Sex discrimination potential of buccolingual and mesiodistal tooth dimensions. Journal of Forensic Sciences, n. 53, p. 790-792, 2008. http://dx.doi.org/10.1111/j.15564029.2008.00778.x

ANUTHAMA, K.; SHANKAR, S.; ILAYARAJA, V.; KUMAR, G. S.; RAJMOHAN, M.; VIGNESH. Determining dental sex dimorphism in South Indians using discriminant function analysis. Forensic Science International, n. 212, p. 86-89, 2011. http://dx.doi.org/10.1016/j.forsciint.2011.05.018

CAMERIERE, R.; CUNHA, E.; SASSAROLI, E.; NUZZOLESE, E.; FERRANTE, L. Age estimation by pulp/tooth area ration in canines: Study of a Portuguese sample to test Cameriere's method. Forensic Science International, n. 193, p. 128e1-128e6, 2009.

FEIJÓO, G.; BARBERÍA, E.; DE NOVA, J.; PRIETO, J. L. Permanent teeth development in Spanish sample. Application to dental age estimation. Forensic Science International, n. 14, p. 213e1-213e6, 2012.

GUO, L.; JIAYIN, R.; SHUPING, Z.; YUANYAUN, L.; NA, L.; WANHONG, W.; SHANSHAN, Y.; HU, W. Dental age estimation from the developmental stage of the third molars in western Chinese population. Forensic Science International, n. 219, p. 158-164, 2012 .

GUSTAFSON, G. Age determinatin of teeth. Journal of the American Dental Association, n. 41, p. 45-54, 1950. http://dx.doi.org/10.14219/jada.archive. 1950.0132

HILL, A. J.; HEWSON, I.; LAIN, R. The role of the forensic odontologist in disaster victim identification: lessons for management. Forensic Science International, n. 205, p. 44-47, 2011.

http://dx.doi.org/10.1016/j.forsciint.2010.08.013

INTERPOL - Disaster Victim Identification Guide. 2009. Available from http://www.interpol.int/INTERPOLexpertise/Forensics/DVI-Pages/DVI-guide. Acess in: March $22^{\text {nd }} 2015$.

JAFARI, A.; MOHEBBI, S. Z.; KHAMI, M.; SHAHABI, M. S.; NASEH, M.; ELHAMI, F.; SHAMSHIRI, A. R. Radiographic Evaluation of Third Molar Development in 5-to 25 Year Olds in Tehran, Iran. Journal of Dentistry, n. 9, p. 107-115, 2012.

JAYAMARAN, J.; KING, N. M.; ROBERTS, G. J.; WONG, H. M. Dental age assessment: are Demirjian's standards appropriate for southern Chinese children? Journal of Forensic Odonto-Stomatology, n. 29, 2011.

KIMURA, R.; YAMAGUCHI, T.; TAKEDA, M.; KONDO, O.; TOMA, T.; HANEJI, K. A Common variant in EDAR is a genetic determinant of shovel-shaped incisors. American Journal of Human Genetics, n. 85, p. 528-535, 2009. http://dx.doi.org/10.1016/j.ajhg.2009.09.006

KRAUS, B. S. Carabelli's anomaly of the maxillary molar teeth. American Journal of Human Genetics, n. 3, p. 348-355, 1951.

LOPEZ, T.T.; BIAZEVIC, M. G.H.; MICHEL-CROSATO, E. National survey of the incidence of missing anterior teeth: potential use in bite mark analysis in the Brazilian context. Science and Justice, n. 50 , p. 119-122, 2010. http://dx.doi.org/10.1016/j.scijus.2009.12.001

LOVEJOY, O.; MEINDL, R.; PYZBECK, T.; MENSFROTH, T. Chronological methamorphosis of the auricular surface of the illium: a new method for the determination of adult skeletal age at death. American Journal of Physical Anthropology, n. 68, p. 15-28, 1985. http://dx.doi.org/10.1002/ajpa.1330680103 
MACALUSO JR., P.J. Investigation on the utility of permanente maxillary molar cusp areas for sex estimation. Forensic Science, Medicine and Pathology, n. 7, p. 233-247, 2011.

http://dx.doi.org/10.1007/s12024-010-9204-7

MEGYESI, M. S.; UBELAKER, D. H.; SAUER, N. J. Test of the Lamendin aging method on two historic skeletal samples. American Journal of Physical Anthropology, n. 131, p. 363-367, 2006.

http://dx.doi.org/10.1002/ajpa.20446

MEINL, A.; HUBER, C. D.; TANGL, S.; GRUBER, G. M.; TESCHLER-NICOLA, M.; WATZEK, G. Comparision of the validity of three dental methods for the estimation of age at death. Forensic Science International, n. 178, p. 96-105, 2008. http://dx.doi.org/10.1016/j.forsciint.2008.02.008

OLIVEIRA, F. T.; CAPELOZZA, A. L. A.; LAURIS, J. P. R.; BULLEN, I. R. F. R. Mineralization of mandibular third molars can estimate chronological age-Brazilian indices. Forensic Science International, 2012. http://dx.doi.org/10.1016/j.forsciint.2011.12.013

PRETTY, I.A.; SWEET D. A look at forensic dentristry - Part 1: The role of teeth in the determination of human identity. British dental journal, n. 190, p. 359-366, 2001. http://dx.doi.org/10.1038/sj.bdj.4800972 http://dx.doi.org/10.1038/sj.bdj.4800972a

SCHULLER-GOTZBURG, P.; SUSCHANEK, J. Forensic odontologists successfully identify tsunami victims in Phuket, Thailand. Forensic Science International, n. 171, p. 204-207, 2007.

http://dx.doi.org/10.1016/j.forsciint.2006.08.013

SONIKA, V.; HARSHAMINDER, K.; MADHUSHANKARI, G. S.; SRI KENNATHI, J. A. Sexual dimorphism in the permanent maxillary first molar: a study of the Haryana population (India). Journal of Forensic Odonto-Stomatology. N. 29, p. 37-43, 2011.

ZAR, J. H. Biostatistical Analysis. 4th ed. New Jersey: Prentice Hall, 1999.

ZORBA, E.; MOIRAITS, K.; ELIOPOLUS, C.; SPILIOPOULOU, C. Sex determination in modern Greeks using diagonal measurements of molar teeth. Forensic Science International, n. 217, p. 19-26, 2012. http://dx.doi.org/10.1016/j.forsciint.2011.09.020 